\title{
The North Atlantic Treaty Organization (NATO), An Obsolete Security Institution or A Group of Self-Seeking Elitists: Re-thinking Reform
}

\author{
Felix Nana Kofi Ofori \\ St Mary's University, Twickenham, London
}

\begin{abstract}
This article argues that elitist tendencies in NATO's leadership coupled with the support of its leading states, induced it to commit humanitarian catastrophes in parts of Europe and Middle East. These mundane policies portray NATO as an entity with blunt strategic vision to protect the security needs of its member states in the $21^{\text {st }}$ century. Similarly, the article contends that, although NATO has played a formidable role in stemming proliferation of nuclear arms and stability of the Euro-Atlantic area, some evidence suggest that the entity has outlived its usefulness. Finally, the article recommends that NATO should divest from its military expeditions in order to acquire new expertise in cyber technology; so as, to remain relevant to the international community thereby contributing towards the stability of the transatlantic project.
\end{abstract}

Keywords: geo-political, strategy, elitism, security, self- interests, obsolete and reform

DOI: $10.7176 /$ IAGS/91-04

Publication date:August $31^{\text {st }} 2021$

Introduction: The Genesis, Objectives and Rationale of NATO

The North Atlantic Treaty Organization (NATO) emerged on $4^{\text {th }}$ April 1949 under the Washington Treaty, as a strategic defence alliance between the United States (US) and some of its counter-part states in Europe; namely Britain, France and Germany, with a view to neutralize Soviet aggression. The formation of NATO was thus motivated by the US' desire to use its foreign policy to neutralize the Soviet's power (Pedlow, 1999). Currently, NATO's activities are broader in scope than at its inception, as briefly summarized below.

The first phase of NATO's operations spanned the period 1949-1989/91 during which NATO's strategic objective was geared to build Europe into a military defensive alliance/partnership and to serve as a bulwark against Soviet aggression. This strategy allowed western European States of the alliance to initiate socioeconomic projects to enhance the welfare of their citizens after lengthy periods of the European wars (Pedlow, 1999). As a consequence, NATO established a strategic military committee (MC3) to organize military manpower as well as a nuclear arms facility to produce atomic bombs (Pedlow, 199). The United States was assigned the responsibility to produce atomic bombs because it had already demonstrated its technical expertise in that field. Although there was disagreement among member states with respect to manufacturing bombs due to its devastating impact on society and humanity, the ambition and desire to ward off Soviet aggression, 'numbed' them into acquiescence (Pedlow, 1999).

The second phase of NATO's operation post-cold war took place in Afghanistan around 2003. According to Robb (2015), the United Nations Security Council (UNSC) authorized the establishment of the International Security Assistance Force (ISAF) in December 2001, with a mandate, to assist the Afghan Interim Authority to secure peace in Kabul and its surrounding areas. However, upon the request of Germany and Netherlands as the nations-in-command of ISAF, NATO was deployed into Afghanistan to play specific roles; namely: Force generation, intelligence, Co-ordination, Information Sharing and Communication (Coelmont, 2009). With the disappearance of Soviet aggression coupled with the unification of Germany, some commentators (Kolko, 2003; Menon and Welsh, 2011), posed the question why NATO still exists. The response to this question is discussed elsewhere in this article. Meanwhile, Skelly (2012) opined that NATO had adopted expedient political measures to admit some emerging states in Central and Eastern Europe as a ploy to prop its existence. Similarly, the admission of Poland, Hungary and Czech Republic into the Alliance was purportedly strategized to stabilize the power vacuum created by the collapse of the Warsaw pact (Bush, 1999).

The third phase of NATO's operation transpired during the Libyan crisis, under the United Nation's Responsibility- to-protect (R2P) principle; in order, to protect the Libyan civilian population against Muamar Gaddafi's indiscriminate killings (Green, 2019). The R2P is a United Nation's principle established in 2005, which mandates a member state to organize military intervetion with a view to prevent a government or political leader from committing genocidal atrocities or human rights violations against its citizens (Mamdani, 2010). Undoubtedly, NATO's military expeditions in Libya and Afghanistan have generated controversies in academic and political circles. However, seeing itself as a transatlantic security organization with a mandate to protect its member states, NATO joined the Afghan war under the R2P principle, to defeat terrorism as well as end terrorrelated crimes. For instance, Friedman (2002) has suggested that the Afghan people's trading activities in 
narcotic drugs coupled with terror-related programmes, was intended to wreak havoc on the global stage. Also, NATO's military expeditions in the afore-mentioned countries have generated several political debates within NATO member states; suggesting that, the military expeditions had resulted in unwanted civilian deaths and destruction of properties (Shabi, 2012; Gallis, 2007). Furthermore, NATO's military expeditions into Libya also drew criticisms from commentators (Mohamed, 2012; Williams and Neumann, 2000) including former President Trump, suggesting that the organization/alliance is desperately engaging in unwarranted wars to rebrand its outmoded image. An example is the NATO's Afghan operations in December 2003 (Gallis, 2007).

As briefly summarised above, NATO was primarily established to stem off Soviet expansion and aggression in Europe; however, with the "implosion" of the Warsaw Pact and dissolution of the USSR", one would have expected that NATO is disbanded since its reason for existence was removed (Sauer, 2017:16). Yet, the continuous existence of NATO coupled with the commission of purported war crimes as well as humanitarian crises, have induced the question: whether NATO is an obsolete entity without the vision to protect the security needs of member states into the $21^{\text {st }}$ century. An attempt to answer this question follows subsequently.

\section{NATO as an Obsolete or 'white elephant' Security Organization}

The view that NATO is an outdated security entity is not a new proposition but a recurrent topic, which has generated comments and debates from presidents, politicians and scholars, as the following examples demonstrate.

First, NATO's engagement in the Kosovo war resulted in the decimation of thousands of human lives and created major humanitarian catastrophes; thereby, drawing condemnations from a spectrum of NATO member states that the entity may have outlived its usefulness. For instance, human rights campaigners and academics (Hobson, 2016; Coker, 2008), had criticized NATO as an outdated alliance struggling to extend its influence beyond the $20^{\text {th }}$ century. Another commentator argues that: "NATO's intervention in Kosovo not only breached the UN Charter but also committed textbook war crimes, which further added to human sufferings by destroying water, electricity and huge numbers of houses" (Murphy, 2000:113). Similarly, the perennial distrust among NATO member-states regarding military expeditions after the cold war had been characterized as a sign of decline; with a commentator, arguing that: "All is not well within NATO itself. The Alliance has locked itself into a posture of strategic indecision, unwilling to embrace the future for fear of losing its relevance" (Coker, 2008:8). The fact that NATO has failed to strategize in dealing with the new security threats of the $21^{\text {st }}$ century cyber-threats/attacks, ideological and religious fanaticism- has created the impression that the entity has outlived its usefulness.

Second, the criticisms of NATO in the wake of the Kososvo war also elicited contradictory responses from the British House of Commons' Foreign Affairs Select Committee; stating that, although NATO's bombing in Kosovo was morally justified; the conduct in international law was illegal (Skelly, 2001). Skelly (2001) alluded to Amnesty International's denunciation of NATO's operations in Kosovo by advocating that it committed series of war crimes with indiscriminate shelling of human lives and health facilities. These criticisms lend support to the view that NATO is not only morally bankrupt with a soiled image, but also a beleaguered entity short of strategic vision to promote the security of its member-states, at the inception of the twenty-first century.

Third, the claim that NATO is an outdated alliance also resonated with the searing pronouncements by some former and current heads of states. For instance, the late President Charles de Gaulle of France, in 1976, withdrew his country from the integrated command shared with the US over the NATO Alliance; and, stated that the latter's intervention in Vietnam was a breach of international law contravening humanitarian principles (Sloan, 2008). De Gaulle's statement not only reflects disunity among the alliance, but also a reflection of NATO that is of little significance to the international community. Similarly, Calleo (1970), has explained that former President Jacque Chirac of France, labelled NATO as an irrelevant security alliance and rebuked new democracies in Central and Eastern Europe, who supported the US' invasion of Vietnam to "learn to shut up." These criticisms reinforce Trump (former US President)'s characterization of NATO as an obsolete entity and a drain on the financial resources of members states (Kaufman, 2017). These characterizations of NATO share semblance of the views of Calleo in 1970 and Kaufman in 2017 respectively. The implication is that NATO's status as a transatlantic entity has waned at the dawn of the $21^{\text {st }}$ century just as it was in the post- cold war era; thereby eroding the people's confidence in its protective capability.

Fourth, NATO has also been framed as an institution in disarray, with the leaders of its prominent member states acting unilaterally to pursue their peculiar self-interests policies. For instance, in 2003, former President George W. Bush launched a unilateral military campaign against Iraq by disregarding the advice of other prominent member states. Kupchan (2004), has stated that Bush's singular policy of invading Iraq without consulting its European Allies, suggests a lack of confidence in the Alliance's leadership. The decision-making process in NATO is primarily based on the distribution of draft proposals by the Secretary-General to member states; who in turn, make amendments, corrections or suggestions to the proposals before voting to accept the 
decision (Michel, 2003). Securing a unanimous decision from NATO member states on proposals symbolizes an approval for those policies/strategies to be implemented (Binnendijk and Priebe, 2019). However, the disagreement/opposition towards Bush's invasion of Iraq boded negatively on the entity; as Germany and other European states refused to support Bush's unilateral campaign in that country. The European states' opposition to Bush's expedition in Iraq is a symptom of an Alliance that is "paralyzing" and "gasping for life" to survive (Kupchan, 2004:12). A 2017 Pew Foundation Poll, as cited by Stokes (2017:7), has indicated that "55 percent of British and 54 of Spanish respondents opposed any military force to defend a NATO ally." Undoubtedly, the evidence above suggests that NATO is divisive and internally fragmented.

Lastly, NATO has been described as an outmoded security organization among some commentators at the collapse of the Berlin Wall and the unification of Germany in 1991. According to McCalla (1996), the dissolution of the Warsaw Pact and the "rebirth" of a united Germany marked an epoch in the history of NATO because the ever- anticipated Soviet threat ceased immediately. Thus, the member states ought to have disbanded or reformed NATO to reflect the new security needs of the times. The late US President, George W. H. Bush and Secretary-General Manfred Worner, shared a common view that NATO had become an irrelevant entity after the unification of Germany in October 1989 (McCalla, 1989). As a consequence, the former US President, W. Bush introduced financial austerity to cut back on the US' contribution, reduced the number of US military personnel and nuclear arms to NATO. The implementation of those strategic policies by the former president freed funds to augment aspects of the US' socio-economic projects (McCalla, 1996). However, there are some sympathizers who hold the contrary view that NATO is still critical and necessary for the security framework of the transatlantic relationship, particularly in the $21^{\text {st }}$ century. Following are arguments supporting that claim.

Simma (1999), a former Judge of the International Court of Justice (ICJ) and professor of international law, had opined that an exception must be made in international law, to authorize member states of the UN to use military power/ force, as a strategy to protect civilians and essential amenities in other countries on humanitarian grounds. The import of Simma's argument is that, NATO and other powerful states should be permitted to violate international law and human rights provision; so long as, the violation is geared at saving innocent citizens from tyrannical regimes as transpired during the Kosovo crisis. Contrary, Hayden (1999) had countered Simma's assertion by stating that NATO's intervention in the Kosovo war resulted in flagrant breaches of international humanitarian law - bombing of civilian properties, health facilities and TV Serbia. Thus, those destructions in themselves undermined the UN Charter as well as Articles 5 and 7 of the Washington Treaty, which established NATO. Furthermore, Hayden (1999) had suggested that NATO's violation of Articles 5 and 7 of its founding treaty, including sections of the UN Charter, portrayed it as a hypocritical institution bent on waging wars so as to secure a self-seeking agenda.

Another defender of NATO holds the view that "Russia pursues aggressive manoeuvring against smaller and weaker states along its eastern borders; thus, a stronger but not proactive presence can serve as a calming influence to the advantage of the United States, Europe and the broader world" (Saab, 2014). This proposition appears contradictory in principle and may potentially undermine the existence of NATO as a security entity for the $21^{\text {st }}$ century, on two grounds. First, Russia's characterization as an aggressor by western powers in the sphere of international relations without the same being said of France, the United Kingdom (UK) and the US, all of whom, support regime change in foreign states is misleading (Payanden, 2011; Kurtz, 2016). For instance, the UK, France and US had recently and openly sponsored and supported militant groups in breach of international and humanitarian laws in Iraq, Libya and Syria (Kuperman, 2015; Kuperman, 2013). Second, the suggestion that a limited presence be maintained to protect the interests of the US and Europeans can best be interpreted as a strategy to promote a geopolitical ambition rather than the security needs of those states in Eastern and Central Europe. This policy characterize the Alliance as Russia-fixated without genuine regard to protecting those eastern blocks (Kwok, 2005; Biermann, 2009; Sauer, 2017). These myopic Russia-centred strategies raise doubts among some statesmen-Trump and Macron- to label NATO as an 'outmoded entity', bent on pursuing unnecessary geopolitical interests.

Similarly, Kaufman (2017) argued that James Mattis, the former US Defense Secretary and former NATO Supreme Commander, had revolutionized the military organ of the Alliance in accordance with the philosophy of combat readiness. Kaufman (2017), argued in support of NATO's policy, that each member state of the Alliance should spend 2 per cent of its GDP on military hardware so as to boost their military strength against the popular enemy- Russia. These polarized views attract opposition stands. For instance, (Lunn and Williams 2017) had suggested that the proposed 2 per cent contribution of national budget towards military armaments and defense equipment, is a drain on the socio-economic prospects of the weaker states of NATO. The above commentators also proposed that those poor member states of NATO should rather invest the 2 per cent of their budgetary contributions to undertake economic and social projects, in the welfare of their citizens.

Furthermore, there is a policy argument, urging NATO to expand its territorial dominance through partnership arrangements with Japan, Australia, New Zealand and some Asian states, to re-assert its influence into the $21^{\text {st }}$ century (Strategic Concept, 2010). In that respect, NATO should endeavour to secure a global status 
as a security entity, seeking to share intelligence with those partners in defeating cyber-attacks and cyber terrorism (Shea, 2007). NATO should thus incorporate this proposition into its new strategic framework with a view to develop expertise to combat some of the emerging threats confronting the Euro-Atlantic. Aspects of this strategy are explored in the recommendation section of this article.

Consequently, the above arguments resonate with the observation of a commentator, that the "organization that symbolizes and operationalizes transatlantic security - may not last forever. But the transatlantic community may have to make serious decisions in the years ahead about the values and interests they are defending and if they still need to do so together" (Sloan, 2016:23). With that observation, the next section explores the idea that NATO has morphed into an elitist entity, framing strategies which address the whims of a few rather the entire community.

\section{NATO as an Elitist Organization}

The claim that NATO is an elitist organization is rooted in theory and backed with practical political commentaries. For example, (Noelie 2016; Alexandra and Paris, 2011; Livanios 2007), posit that an elitist institution seeks and strives for power and influence to promote the selfish interests of a hierarchy; whilst, Burns and Carson (2002) had stated that elitist organizations exhibit leadership traits, which engage the media to exert political pressures as well as pursue lobby-related functions for its interests. Some examples illustrating elitist traits of NATO are below.

First, the requirement that each member state of NATO should spend 2 per cent of its budget on defense and military equipment is perceived among some states/commentators, as a collusion and connivance among NATO's leadership and the military industrial complex, to advance economic and political benefits (Plitnick and Toensing, 2007; Ikedinma, 2017; Plitnick and Toensing, 2007). This policy initiative is exploited by NATO‘s leadership to mount pressure on member states, especially the weaker ones, to purchase military war planes and related armaments. Beyond purported security needs, this policy initiative has been denounced in parts of Europe and America as a strategy to boost the financial fortunes of the military industrial complex. By this action, NATO postures as a "salesperson" for the military industrial complex, seeking to gain material favours and also entrench its position as an international security organization (Dunne and Skons, 2014; Slijper 2005).

Second, the elitist theory proposes that a coalition of interest groups which are often found in public administrative positions, may emerge to advance an agenda that seems to serve the relevant communities they represent, but in reality, protecting their hidden and egoistic interests (McFarland, 1987). Interestingly, this characterization aptly sums and fits NATO's leadership role, because it is committed to advancing its own political and power interests by imposing policies and directing member states to purchase armaments with a percentage of their national budget. Furthermore, NATO's leadership has been forging closer relationship with heads of governments, in the White House and Westminster; in order, to project its image as a powerful security entity of the $21^{\text {st }}$ century. This objective is being realized with an obsession to neutralize the so called "Russian aggression" (Williams and Neumann, 2000). Those elitist tendencies often entail military postures, which are demonstrated in the combative exercises undertaken by NATO forces at the Eastern borders of Russia and in Norway recently (Palmer, 2016). The consequences of such elitist orchestrations adversely affect the politics of communities where NATO's influences hold sway (Eastern Ukraine).

\section{The Impact of NATO's Elitism on the Internal Politics and Security of Member States}

One argument is that NATO and its leading states are adept in manipulating political tensions within proxy states under the guise of Russian aggression; in order, to coerce member states to increase their spending on military hardware and to be prepared for future wars. Kosekenniemi argues that: "the powerful states within NATO constantly fail to act in the best interests of the world community. Rather, nations like-Germany, France, UK and US act only in situations that are congenial with or promise to advance their own political interests" (Kosekenniemi, 1995: 6). Kosekenniemi's statement seems to underline the obsessive policy initiatives of NATO states to incite war or regime change in foreign states- Libya and Iraq. Although Russia's contributions in fomenting political and security tensions in the international arenas is undeniable, in some cases, Russia has shown goodwill and respect for international law by proposing peaceful and conciliatory strategies to resolve conflicts, in Syria, Iran and Ukraine without acceptance from NATO states (Brooks and Wohlforth, 2016). Russia has also shown good-will to resolve conflicts in the following cases. It negotiated the destruction of Syria's chemical arsenal as well as a peace deal between Assad and his opponents (Nikitin, 2017); Russia resolved the Nagorno-Karabash conflicts at the expense of its political and economic interests (Klever, 2013).

The fact that leading NATO states securitized feeble internal struggles in Eastern and Central Europe, to promote their political ambitions and elitist interests, by rejecting peace proposals (NATO rejected Russian AirSafety Protocol, Barnes 2016); indicates, that NATO states see security tensions in Eastern and Central European states as an opportunity to achieve territorial expansion on Russian borders. Similarly, NATO's disregard for political solutions to stemming conflicts reflect its strategy for stoking tension as evidenced in the cases of Libya 
and Iraq. Thus, Koskenniemi has criticised NATO's policy by arguing that: "the lack of legal culture within NATO is characteristic of an elitist organization ... whose primary responsibility is the maintenance of a political intervention ordering and influence" (Koskenniemi, 1995:460). Just as in Iraq and Afghanistan, NATO's penchant to organize its forces closer to the Russian frontiers coupled with its repeated attempts to overthrow Bashar -Al -Sad of Syria, with donations of arms and war equipment to the opposition forces; represents an insatiable desire of NATO's leadership to induce regime change rather resolve the conflict peacefully (Engelbrekt and Wagnsson, 2013). Furthermore, the fact that dialogue and negotiation had played little role in NATO's strategy of conflict management suggest that the organization is fixated in creating insecurity and political destabilization among proxy states for its expediency.

Second, the claim that NATO's elitist culture foments insecurity and political tension in proxy states manifests in its determination to secure territorial advantage against Russia. Hayden (1999:92) has argued that the zeal of NATO's leadership to commit ground military forces into Iraq portrayed it as an elitist entity, seeking to carve a reputation as indispensable security organization in international affairs. This strategy not only epitomizes NATO as an elitist organization pursuing world recognition, but also as an entity obsessed with power to influence global and domestic security issues. For example, NATO's Secretary-General, Stoltenberg, is said to have the tendency of aligning himself with senior members of the US administration, especially former US Defense Secretary General James Mattis. Also, this attempt of NATO's leadership to associate with the American and British political leaders, is interpreted as a ploy to hold extensive sway in shaping major policies of the alliance (Webber, 2009). Thus, NATO's leadership is motivated to engage with those powerful persons, in order, to promote its strategic policies in member states. Furthermore, Goldgeier (1999) makes the point that self-seeking interests and elitist tendencies conspired to persuade NATO policy entrepreneurs, to incite political destabilization in weaker Eastern European states (Serbia and Montenegro). Thus, it is argued that such proposition reflects Stoltenberg's determination to actively canvass for the implementation of the 2 per cent budget spending on military infrastructure, in all NATO states.

Third, the adoption of a "bogey man" and securitization strategies by NATO and its allied powers (USA, UK, France and Germany), is a classic example of exploiting elitism to create political instability in foreign states. Simply, a "bogey man" tactic uses an allusion and mythical phenomenon to frighten people into submission. Securitization is a minor political issue that is treated by the principal as an extremely dangerous development, with the prospect to foment and threaten human existence, thus needing an immediate response (Balzacq and Guzzini, 2006). NATO has engaged these strategies to create political divisions in Ukraine and elsewhere. In the words of a Russian diplomat: "Today, the West's continued advance is tearing apart the countries on Russia's borders. It has already led to territorial splits in Moldova and Georgia, and Ukraine is now splitting before our very eyes" (Lukin, 2014:87). The political crisis in Ukraine has received mixed commentaries from commentators (Wolff, 2015; Freedman, 2014). Besides securitization, there is also a belief that NATO, is motivated much as Russia, by geo-political considerations, to gain formidable presence in Ukraine so as to neutralize one another. The interplay of the geopolitical interests between NATO and Russia are contributory factors to elongating the conflict in Ukraine (Tsygankov 2018; Larrabe, 2007). Although the above factors implicate both NATO member states and Russia of complicity in the political tension in Ukraine, there is also a deep concern among Russians that NATO and its Western powers are selfishly sponsoring the conflict to undermine its existence (Renz, 2019; Marten, 2017). The impact of this adverse strategy creates hardships for the ordinary Ukrainians and Russians in the spheres of economics, social and political.

Fourth, there is another suggestion that NATO's repeated failure to abandon its expansionist policy on the eastern borders of Russia, reflects an elitist strategy which promotes the parochial political interests of the Alliance with an intent to destabilize the livelihoods of the peoples in the Eastern and Central Europe. For example, Gardner (2014) states that NATO's integrated military command in the Black Sea and Caucasus region coupled with the deployment of US Missile defense systems in Poland, the Czech Republic and Turkey without a corresponding Russian aggression towards the allies, is a testament to the adverse elitist policies of NATO's leadership. Thus, Russia's annexation of the Crimea, which holds nearly seventy per cent of the Ukraine's Russian-speaking population, was in rebuttal to that elitist strategy of encroaching on its space. This may be a recipe for potential conflict with a disastrous consequences for the socio-economic wellbeing of those living in that region. As a strategy of easing tension in the region, Gardner (2014) has proposed that the annexation of Crimea presents an opportunity for a future positive relationship among Europeans, NATO, US and Russia. This means that the affected parties should engage dialogue to promote peace so as to stem unwanted further disturbances. However, to achieve peace, leadership of NATO negotiate with Russia in good faith by abandoning its elitist ambitions.

Fifth, the other argument ascribing NATO as a promoter of political and security tensions is attributed to its aggressive expansionist policy, which is disguised to protect Serbia against Belgrade's 'aggression'. Carpenter (2000) denounces such a policy, arguing that: "Such hectoring further damaged Russian-NATO relations that had already been frayed by NATO's eastward expansion and even, more so, by the Alliance's intervention in the 
Balkans" (Carpenter, 2000:18). In addition, NATO's ploy to expand its influence at the Russian borders is regarded, in some circles, as a provocative tactic intended to elicit confrontation with Russia. An example is NATO's tactics in Ukraine: "And as a leaked telephone recording revealed, Nuland had advocated regime change and wanted Ukrainian politician Arseniy Yatsenyuk to become prime minister in the new government, which she did. No wonder Russians of all persuasions think the West played a role in Yanukovych's ouster" (Mearsheimer, 2014:81). Furthermore, Mearsheimer (2014) explained that the US played a leading role as a NATO state in ousting Yanukovych through the engineering of political instability in Ukraine that conforms with elitist traits of the Alliance. This indicates that NATO often uses covert and overt tactics to achieve geopolitical objectives, which satisfy a sectional interest of the leadership without recourse to the people's welfare.

Although President Maduro's economic policies had contributed partly to the sufferings and hardships facing Venezuelans, the policy of regime change proposed by the US and supported by the NATO leadership (Meyerson, 2020), will hardly resolve the crises in that country. The determination to achieve elitist interests at the expense of troubled and weakened states within and without NATO's jurisdiction, is nothing short of a geopolitical and economic overtures. Besides human deaths and misery, the destruction of socio-economic policies of weaker states, especially Venezuela, through inhuman sanctions, suggests that most of the wars started by the US -backed NATO, have hardly produced peace or stabilize a democratic governance. Some examples can be found in Afghanistan, Libya and Iraq. The lesson is that a political solution rather war should be the preferred strategy to managing conflict in the world (Meyerson, 2020). However, one cannot gloss over the fact that NATO has achieved some remarkable feats in the context of international security, as the following examples demonstrate.

\section{NATO's Achievements: Promoting Security, Humanitarian Assistance and Global Security}

One of the enduring achievements recorded by NATO since its inception is the stability provided to the EuroAtlantic area after the cold war era. According to Berdal and Ucko (2009), NATO played a key role in stabilizing the Euro-Atlantic areas to ensure that member states undertake internal political, social and economic restructuring, which were vital to promote the wellbeing of their citizens. The need for economic and social development is crucial for every state and region, especially after lengthy years of wars; therefore, the fact that NATO contributed to maintaining stability within the Euro-Atlantic area post-cold war is a commendable feat. Also, NATO is credited with playing a pivotal role in protecting and stabilizing Albania and the surrounding Balkan states, to ward off the aggression of the Serb-Croatian forces (Solana, 1999). Although this particular achievement is contested in some academic circles, there is a view that NATO merits praise because failure to institute peace in the area would have thwarted the progressive economic and social developments taking place in Western Europe.

Second, related to Albania and contrary to popular belief, Solana (1999) argued that NATO's operation in Kosovo and Yugoslavia had been the biggest success of the Alliance; primarily, because the intervention achieved the dual purpose of stemming a humanitarian disaster by restoring law and order in the area. Buttressing the argument for NATO's expeditionary success in Kosovo, Solana (1999) alluded to the fact that Russia contributed and collaborated with the Kosovo Implementation Force (KFOR) to maintain order as well as engaged with NATO in finding solutions to the eastern European crises. Similarly, Davutoglu (2012) affirmed Solana's argument that although the Alliance's intervention in Kosovo and Herzegovina was an out-of- territory expedition, the objective to save humanity and restore peace made it a resounding success. As a former NATO Secretary-General and a leading policy -advocate of the Alliance, there is little doubt that Solana would say anything that undermines the existence of the entity. However, some arguments in this article and other academic publications hold opposing views regarding the success of the Kosovo intervention.

Third, the strategic transformation of NATO into a quasi- global security entity beyond the Euro-Atlantic area is recognized by some member states as a novel achievement. For instance, Kanet and Larive (2012) have stated that granting membership status to Georgia, Ukraine (being considered) as well as the erection of the missile defence systems in parts of Eastern Europe including Poland and Turkey, was a protective response to Russia's illegal invasion of Tbilisi in 2008. By drawing Georgia and Ukraine into NATO's fraternity, one expected that Russia would be compelled to restrain its "aggressive threats" towards other weakened states. Perhaps, with the presence of the missile defence system in Eastern Europe, the Alliance had hoped that Russia would be calmed into submission. However, the opposite happened. Russia swiftly annexed the Crimea whilst factions loyal to Ukraine and Russia kept fighting destructive battles in some parts of Ukraine (Malkosoo, 2019; Charron, 2014). While one cannot see an end to the Ukraine war, the people in Eastern Ukraine and the other countries in which the missile defence systems are mounted, live in danger of future reprisals. The fact that these missile defence systems were mounted in poor states of the NATO Alliance rather in France, UK or Belgium is very telling. These military installations are intended to perpetuate the political and territorial-interests of the powerhouses of NATO so as to stem Russia's aggression towards member states in Eastern Europe (Erlanger, 
2016).

Lastly, NATO's contribution to the protection of human security and implementation of humanitarian strategies came in 2005, when the then Chairperson of the Commission of African Union (AU), Mr Apha Oumar Konare requested the Secretary-General of NATO to assist with peacekeeping forces and logistical equipment to complement the effort of the African Union Mission in Sudan (AMIS); so as, to quell the fighting and stop the killings of vulnerable Sudanese. According to Segell (2011), that was NATO's first African expedition in respect of the "out of-territory policy". Segell (2011) pointed out that the AMIS lacked the requisite experience and logistics to deal with the conflict; thus, in addition to a formal request made to NATO's Secretary-General, Mr Konare visited the headquarters of NATO in Brussels to demand the deploying of peacekeeping forces to Sudan. Marrone (2011), who saw NATO's engagement in Sudan as an achievement as well as a platform to extend the partnership policy, stated that, it is the best initiative for NATO to venture into future collaborative alliances with states in Africa, Asia and the Pacific to undertake joint security operations.

Contrary, scepticism has been raised over the viability of the strategic partnership. A commentator observed that: "Indeed, the conundrum of how to broaden NATO's partners beyond Europe while at the same time remaining true to its own identity as an Alliance grounded in liberal democratic values is one that has plagued NATO for some time ..." (Moore, 2012:68). It is well recognized that NATO has contributed to the maintenance of peace and stability in the Euro-Atlantic area after the cold war.The view that NATO's 2010 Strategic Document constitutes the best viable policy to steer the Alliance through the $21^{\text {st }}$ century is explored in the following session.

\section{The New Strategic Concept (2010) - NATO: Active Engagement, Modern Defence}

First, the Strategic Concept Document emerged out the Lisbon Summit of 2010. The new direction of NATO's strategy policy is reflected in the following sentence: "This Strategic Concept will guide the next phase in NATO's evolution, so that it continues to be effective in a changing world, against new threats with new capabilities and new partners" (NATO, 2010;4).

NATO's Strategic Concept of 2010 declared its intention to reduce nuclear proliferation. The document proposed, among other things, that NATO is committed to reducing its nuclear ammunition in consonance with the Nuclear Non -Proliferation Treaty (NPT), to create a stable world in which peaceful co- existence is guaranteed for its member states and the international community as a whole, (Strategic Concept, 2010: 25). Some conflicting arguments had been made by NATO's leading member states - US, UK and France- to stock nuclear arms and other deadly weapons, as a pretext, to hopefully "prevent North Korea, Iran and non-state actors from destabilizing the international security order", (Scheber 2007:124). The international community praised NATO for striving to curb the proliferation of nuclear (Alberque, 2017). However, Meier (2010) suggests that the disagreements among key NATO member states regarding the abolition of nuclear armaments is an indication of an alliance in disarray over policy and strategic choices.

The temporary ban of nuclear testing in North Korea, tenuously achieved between Kim Jung Un and Trump over a short span of time was mainly due to dialogue. The lesson is that, in many cases, dialogue holds key to resolving conflicts/wars more effectively than arms-conflicts, provided the parties commit to negotiating in good faith. NATO will help to promote peace within the transatlantic spheres and the world at larger if it learns to pursue dialogue as a strategy at the expense of military expeditions. Conflicts no longer command the interests and support of member states of the Alliance because history teaches that war only destroys and maims (Coker, 2008).

Second, at paragraph 38 of the Strategic Concept Document (2010), NATO states that it is committed to forming an alliance for the $21^{\text {st }}$ century with a politico-military objective to advance human rights, democratic values and security for all member states. However, there is doubt about NATO's capacity to promote peace and democratic values in the sphere of international security, (Reiter, 2001; Epstein, 2006). The commitment by NATO to advance democratic values in conflict-prone regions failed in Libya and Afghanistan. NATO's persistent push for member states to spend 2 per cent of their budgetary allocation on military armaments betrays its commitment towards de-nuclearization and/ or promotion of democratic values.

Third, combating cyber-attacks within member states was a prime policy objective in the NATO's Strategic Concept (2010). The issue of cyber-protection in the Alliance emerged from the Wales Summit in 2014, and it was intended to educate and equip member states with strategies to combat cyber-attacks; as transpired in Estonia in 2006, where that country's information technology and digital infrastructures were paralysed (Hughes, 2009). Russia, a securitization candidate, was conveniently labelled the culprit for the Estonia cyber-crisis (Hughes, 2009). Thus, the Estonia cyber- crisis formed the basis of NATO's discussion and policy formulation at the Bucharest Security Agenda Summit, in 2009 (Hughes, 2009). An expert explained that although the hate for Russia is perceived to be in the 'DNA of America', leaders of other NATO states often encourage war with Russia, in order to satisfy the military industrial complexes financially, rather than promoting the peace and security of the international community (Kovalik, 2018). Similarly, Stebbing and Comen (2019) have alluded to 
close business dealings between NATO with Airbus Group and Leido's Virginia- based Technology Companies laced with financial rewards. Interestingly, the issue of cyber-attack is one area in which NATO is expected to devise a novel policy to acquire a new expertise with which to rebrand its image in the 21 st century. Yet, the failings of NATO to deal with cyber-attacks of the non-kinetic defense operations in Montenegro should challenge the Alliance's resolve to develop an expertise in that field at the expense of military capability (Galeotti, 2017).

Lastly, Volker and Green (2011) argued that NATO's Strategic Concept represents a new strategic policy initiative, which may address the international security needs of its member states, especially in the area of cyber security. This view resonated with the proposition of a commentator that: "The Lisbon document's flexibility also allows for further adjustment in the light of the fast-changing security environment. All these elements make the 2010 Strategic Concept a positive tool to influence ongoing and future NATO activities" (Marrone, 2011:110). This proposition exudes some confidence among member states that NATO's Strategic Policy Document of 2010 addresses their security concerns. Conversely, emerging international security developments within the Euro-Atlantic area coupled with majority of security threats on the global stage (religious, ideological fanaticism and terrorism) pose a different picture. The reason is that NATO's 'strategic Concept' of 2010 appeared myopic and inadequate to address the above stated challenges confronting the international community of which NATO is a party. This calls for a rethinking of the strategy and possibly a novel reform devoid of militaristic expeditions as explored in subsequent section of this article.

\section{Re-thinking/Re-forming NATO to meet the New International Security Threats of the Twenty-First Century}

Military and expeditionary forces can be effective. They can influence policies of some states to conform to the 2 per cent budget spending on military hardware. Nevertheless, as growing dissention toward military intervention and expeditions reveal, they have limits (Betts and Collier, 2017:109). Most NATO member states, including prominent and newly accepted states, are ignoring the tenets of the Washington Treaty of 1949. The tenets of the Washington/NATO Treaty call for collective defence and preservation of peace and security of member states as well as the transatlantic area. Contrary, Turkey, Poland and Hungary are among some of the member states which opposed NATO tenets (Dempsey, 2018). These developments confirm the view of Krasner (1983) that states comply with treaty when it aligns with their interests. The recommendations below are intended to help NATO restructure itself and policies so as to meaningfully protect the international security of its member states, and by extension the international community.

- $\quad$ NATO should become a security organization that is a peace broker, proposing and promoting new agreements with governments in the hope of establishing peaceful co-existence devoid of arms-race and military build-up. Thus, it needs to be proactively setting the agenda by strategically leading governments to work towards a peaceful international security policy.

- As a way of reducing internal conflicts in member states, especially in the newly established democracies of East-Montenegro and Hungary, regarding Articles 4 and 5 of the Washington Treaty, NATO should focus on seeking a new technical capability in cyber security protection, by reformatting its existing infrastructures. This will allow NATO to establish itself as a think-tank with the prospects of offering intelligence, advice, and capacity-building to help its member states stem such threats. This strategy will afford the member states the freedom to invest 2 per cent of their budget in socioeconomic projects- education, hospitals, and scientific ventures, research projects- that produce opportunities for employment, economic growth and good health that constitute the basis of development rather than war, which threatens the wellbeing of society.

- $\quad$ The European Security and Defense Identity project created by NATO and EU to deal with crises if and when they arise. The wisdom behind the creation of this body/organ maybe to strengthen the hands of Europeans to exercise sound and thoughtful judgments before engaging in any conflict management without committing resources which would be better spent on the socioeconomic development of their peoples and nations. Also, this policy will reduce their dependence on external forces, especially the US which prefer to dictate security and military strategies which are not in conformity with the Europeans' objective. The European Union should endeavour to establish itself as an organization competent, capable and independent in not only economic prosperity, but also as a recognized security force with the requisite resources to protect its security whenever the need arises with no/les dependence on the United States.

- The strategy of winning 'minds and hearts' should be given priority in the policies of NATO, as it will project a new image of the entity in the international security arena. Realizing the limitations of warplanes, bombs, guns and allied military armaments, General Stanley McChrystal proposed the novel idea of engaging with the enemy's 'minds and hearts' as a durable and worthy conflict resolution strategy. The basis of the 'minds and hearts' principle is that human beings can be aroused emotionally 
to empathize with an issue to which they do not initially agree. This principle requires the use of emotional intelligence coupled with respect and dignity for those with whom one shares no belief or conviction. Thus, NATO should start engaging with their purported 'enemies' (Russia and others) by relying on the advice of General McCrystal, to build a collaborative relationship based on mutual trust and, as partially transpired in 2008 under the KFOR peacekeeping project in Kosovo.

- Scrutiny of NATO policies and international security issues should be given critical examination at the national levels, particularly by national legislatures. By subjecting such policies to rigorous debates within national parliaments/assemblies, budgetary contribution towards military hardware coupled with wanton and reckless deployment of military forces will be minimized to curtail the elitist ambitions of the NATO leadership, the military industrial complex and allied security organizations- namelyCollective Security Treaty Organization (CSTO). This will not only protect the member states against unnecessary budgetary expenditures but also reduce incidences of human rights violations, as occurred in Afghanistan, Libya and Kosovo.

\section{Conclusion}

The $21^{\text {st }}$ century marks a new beginning for NATO to refrain from elitist tendencies disguised in its self-seeking policies of military expeditions. The strategy of inciting proxy wars and securitizing minor internal conflicts as reasons for promoting huge military budgets have peaked, and designating Russia as the bogeyman as well as the cause of every political disturbance in Eastern and Central Europe is less effective. NATO needs new ways of influencing the security landscape of the $21^{\text {st }}$ century and dialoguing strategically with Russia to find sustainable peace plans to curb the conflicts in Eastern and Central Europe, is an effective alternative to military expeditions. The nineteen-century security threats have no significance at the dawn of the $21^{\text {st }}$ century.

In security terms, NATO's Strategic Concept of 2010, accepted by a majority of member states as the blueprint of global expansionist agenda for the $21^{\text {st }}$ century is a frivolous plan. This is because the ideals of partnership with Australia, New Zealand and cooperation with some Asian states are out-dated and unappealing, sinec leading NATO states- France and Germany opposed it. NATO needs to accept that its primary purpose is security of the Euro-Atlantic area. Even that purpose is fast eroding as the European Union is building a security force to protect its interests.

As history teaches, no sustainable security, democracy, economic or political objective is achievable, either on the Euro-Atlantic horizon or in the international community, by resorting to the deployment of military forces or armaments. The Libyan crisis offers a lasting testimony of the limitations of war in promoting democracy. This should induce a sober reflective spirit among NATO and its leading states, to contemplate the rich and enduring virtues of negotiating for peaceful settlement of all conflicts. To a very large extent, the favourable view is that, NATO is indeed outdated for the $21^{\text {st }}$ century, it needs to divest from militarism in order to acquire a novel expertise, possibly in cyber-intelligence to remain significant.

\section{References}

Alberque, W. (2017). The NPT and The Origins of NATO's Nuclear Sharing Agreements, IFRI Security Studies Center, February Proliferation paper, 57.

Alcaro, R. (2010). Combining Realism With Vision: Options for NATO's New Strategic Concept, Instituto Affari Internationazionali, Documenti, 10/17, 1-18.

Balzacq, T. and Guzzini. (2006). Introduction: What Kind of Theory -If Any- Is Securitization? International Relations, 29(1), 97-102.

Baylis, J. (1987). NATO Strategy: The Case for a New Strategic Concept, The Royal Institute of International Affairs, 64(1) 43-59

Berdal, N. and Ucko, D. (2009). NATO at 60. Survival, 51(2), 55-70.

Betts, A. and Collier, P. (2017). Refuge: Transforming a Broken Refugee System. Gt. Britain, Allen Lane.

Biermann, R. (2009). NATO's Institutional Decline in Post-Cold War Security Governance, in C. Wagnsson, J. Sperling, and J. Hallenberg, (eds), European Security Governance: The European Union in a Westphalian, London, Routledge.

Binnendijk, A. and Priebe, M. (2019). An Attack against the All? Rand Corporation.

Bolkus, C. A. (2011). Global NATO: An Identity Based Account of the Alliance in the 21 st Century. https://lup.lu.se/luur/dowload?func=downloadFile\&recordOld=1975688\&fileOld=1975692, accessed November 27, 2020.

Brooks, S.G. W.C. Wohlforth, C. W. (2016). America Abroad: The United States' Global Role in the $21^{\text {st }}$ Century. Oxford University Press, Oxford, 2016.

Burns, T.R. and Carson, M. (2002). European Union, Neo-Corporatist, and Pluralist Governance Arrangements: Lobbying and Policy-making Patterns in a Comparative Perspective. International Journal of Regulation and Governance, 2(2), 129-175. 
Bush, G. (1989). A Whole Europe and Free. Remarks to the Citizens in Mainz. President George Bush. Rheindoldhalle. Mainz, Federal of Germany, May 31, 1989. Available at www.usa.USembassy.de , accessed November, 272020.

Calleo, David. (1970). The Atlantic Fantasy: The US, NATO \& Europe, Baltimore, John Hopkins University Press.

Canby, L. S. (1977). The Future of Europe and NATO's Outdated Solutions, International Security, 160-162.

Carpenter, G. (2000) NATO's New Strategic Concept: Coherent Blueprint or Conceptual Muddle? The Journal of Strategic Studies, 23(3) 7-28.

Charron, A. (2014). Russian Recolonization of the Crimea, Current History, 119 (819) 275-281.

Coelmont, J. (2009). End-State Afghanistan: A European Perspective, Brussels, Royal Institute for International Relations

Coker, C. (2008). Why NATO Should Return Home: The Case for a Twenty-first Century Alliance, The RUSI Journal, 153(4) 6-11.

Davutoglu, A. (20120. Transformation of NATO and Turkey's Position. Perceptions: Journal of International Affairs, Spring, 27 (1) 7-18.

Dempsey, J. NATO’s Bad Apples, Carnegie Europe, (April 3, 2018).

Dunne, J. P. and Sköns, E. (2014) the Changing Military Industrial Complex. London, Routledge Handbook.

Engelbrekt, K., Mohlin, M. and Wagnsson, C. eds., (2013). The NATO intervention in Libya: lessons learned from the campaign. Routledge.

Epstein, R.A., (2005). NATO Enlargement and the Spread of Democracy: Evidence and Expectations. Security Studies, 14(1), 63-105.

Erlanger, S. (2016). NATO Ratchets Up Missile Defense Despite Russian Criticism. The New York Times, (May 5, 2016)

Freedman, L. (2014). Ukraine and the Art of Limited War. Survival, 56(6), 7-38.

Friedman, L. (2002). Longitudes \& Attitudes: Exploring the World after September 11. New York: Farrar, Straus, Giroux.

Galeotti, M., (2017) Trump was Right: NATO is Obsolete, Foreign Policy, July 20 available at https://foreignpolicy.com/2017/07/20/trump-nato-hybrid-warfare-hybrid-defense-russia-putin/ accessed November 4, 2020.

Gallies, P. (2007). NATO in Afghanistan: A Test of the Transatlantic Alliance, Connections, vol.6, No.3, Fall, 10-32.

Gardner, H., (2014). NATO, the EU, Ukraine, Russia and Crimea: the "Reset" that was never "Reset". NATO Watch Briefing Paper, 49, available at https://natowatch.org/sites/default/files/briefing_paper_no_49_ukraine_russia_crimea.pdf accessed November 4, 2020.

Ghecinu A. and Paris, R. (2011). NATO and the Challenging of Sustainable Peacebuilding, Global Governance, 17 (1), available at: https://DOI:10.1163/19426720-0017011005 accessed November 4, 20202.

Gilens, M. and Page, B.I. (2014). Testing Theories of American politics: Elites, interest groups, and average citizens. Perspectives on politics, 12(3), 564-581.

Goldgeier, M. J. (1999). Not Whether But When: The US Decision to Enlarge NATO. USA. Brookings Institution Press.

Hayden M. Robert. (1999). Humanitarian Hypocrisy, 8 East European Constitutional Review. (91), 91-96.

Higley, J. Hoffmann-Lange, U., Kadushin, C. and Moore, G. (1991). Elite Integration in Stable Democracies: A Reconsideration. European Sociological Review, 7(1), 35-53.

Hobson, C. (2016) Responsibility to Failure: The Responsibility to Protect after Libya. Millennium Journal of International Studies, 44(3), 433-454.

Holbrooke, R. and Asmus, R., (2006). Next Step for NATO. Washington Post, available at https://www.gmfus.org/commentary/next-step.nato, accessed November 2020.

Hughes, R., (2009). NATO and Cyber Defence. Atlantisch Perspectief, 33.

Iida, Y., (2006). Formalized Discourse and the Specter of Phantom Language: The Rise of Elitist Hegemony in Contemporary Japan. Canadian Political Science Association Annual. 1-9.

Ikedinma, H.A., (2017). Impact of Military Spending on African Development. Ife Social Sciences Review, 25(1), 98-111.

Jacobson, D., (2003). Europe's Post Democracy?. Society, 40(2), 70-76.

Kanet, E. R. and Larive, M.H. A. (2012). NATO and Russia: A Perpetual New Beginning. Perceptions: Journal of International Affairs, 27(1) 75-92

Kaufman, J.P. (2017). The US Perspective on NATO under Trump: Lessons of the Past and Prospects for the Future. International Affairs, 93(2), 251-266.

Keller, Patrick. (2012). Germany in NATO: The Status- Quo Ally. Survival, 54(3), 95-110.

Klever, E. (2013). The Nagorno-Karabakh Conflict between Armenia and Azerbaijan: An Overview of the 
Current Situation, European Movement International. Sept 24. Brussels.

Kolko, G., (2003). Iraq, The United States, and the End of the European Coalition. Journal of Contemporary Asia, 33(3), 291-298.

Koskenniemi, M. (1995). The Place of Law in Collective Security. 17 Mich. J. Int'l L. 455, 456-488.

Kovalik, D. (2018). The Plot to Overthrow Venezuela: How the US is Orchestrating a Coup for Oil. USA, Simon \& Schuster.

Krasner, S.D. ed. (1983). International Regimes. Cornell University Press.

Kurtz, G. and Rotmann, P., 2016. The evolution of norms of protection: Major Powers debate the responsibility to protect. Global Society, 30(1), pp.3-20.

Kupchan, A. Charles. (2001). End of the West, Atlantic Monthly, November, 2-21.

Kuperman, A.J. (2013). A Model Humanitarian Intervention? Reassessing NATO's Libya Campaign. International Security, 38(1), 105-136.

Kuperman, A.J. (2015). Obama's Libya Debacle: How a Well-Meaning Intervention Ended in Failure. Foreign Affairs. 94, 66.

Kwok, J. (2005). Mending NATO. Harvard International Review, 27(2), 36.

Larrabee, F.S. (2006). Ukraine and the West. Survival, 48(1),93-110.

Lauren, A. (2002). The War over Kosovo and the ICTY Investigation, American University of International Law Review, 17(4), 765-814.

Leonid, I. F. (2018). Russia

Livanios, D., (1999). Truth and Ethnic Truth in the Balkans (or how NATO 'helped' Milosevic). Cambridge Review of International Affairs, 13(1), 205-217.

Lukin, A. (2014). What the Kremlin is Thinking: Putin's Vision for Eurasia. Foreign Affairs, 94 (3) 85-93.

Lunn, S. and Williams, N. (2017). NATO Defence Spending: The Irrationality of 2 \%. European Leadership Network, Jun, 1-9.

Malksoo, L. (2019). The Annexation of Crimea and the Balance of Power in International Law, European Journal International of Law, 30 (1) 355.

Mamdani, M. (2010). Responsibility to Protect or Right to Punish, Journal of Intervention and Stability, 4 (1) 53-67.

Marrone, A. (2011). The Equilibrium of the 2010 NATO Strategic Concept. The International Spectator, 46 (3) 93-111

Marten, K. (2017). Reducing Tensions between Russia and NATO. Council on Foreign Relation- Council Special Report No. 79 (Mar. 2017).

McCalla, Robert. (1996). NATO's Persistence after the Cold War. International Organization, 50(3), 445-475.

McFarland, A.S., (1987). Interest Groups and Theories of Power in America. British Journal of Political Science, 17(2), pp.129-147.

McGregor, Lorna. (2001). Military and Judicial Intervention: The Way Forward in Human Rights Enforcement. Ind. Int'l \& Comp. L. Rev., 12, 107.

Mearsheimer J. J. (2014). Why the Ukraine Crisis in the West's Fault: The Liberal Delusions that Provoked Putin, Foreign Affairs, 97 (77), 77-89.

Meier, O. (2010). NATO Chief's Remark Highlights Policy Rifts. Arms Control Today, May, 40 (4), 35-37.

Meier, O. and Ingram, P., (2010). A Nuclear Posture Review for NATO. Arms Control Today, 40(8), 8.

Menon, A. and Welsh, J., (2011). Understanding NATO's Sustainability: The Limits of Institutionalist Theory. Global Governance: A Review of Multilateralism and International Organizations, 17(1), 81-94.

Meyerson, S. (2020) How to Fail Regime Change. Harvard Political Review, Jan 22, 1-7.

Michel, G. L. (2003). NATO Decision-making: Au Revoir to the Consensus Rule? Strategic Forum, Aug, No. 202.

Mohamed, S. 2012. Taking Stock of the Responsibility to Protect. Stan. J. Int'l L., 48, 319.

Moore, R. R. (2012). Lisbon and the Evolution of NATO's New Partnership Policy. Perceptions, Journal of International Affairs, spring, 27(1) 55-74.

Murphy, D. (1999). Contemporary Practice of the United States relating to International Law, American Journal of International Law. 93(3) 628-632.

NATO. (2010). Strategic Concept for the Defence and Security of the Members of the North Atlantic Treaty Organization. Available at https://www.nato.int/strategic-concept/pdf/strat_Concept_web.en.pdf accessed November 24 November 2020.

NATO: Active Engagement, (2010)Modern Defence (Strategic Concept) adopted by the Heads of States of Government at the NATO Summit in Lisbon, (19-20 November) available at https://www.nato.int.lisbon2020/strategic-concept-2020-eng.pdf accessed November 27, 2020.

Nikitin, A. (2017). International Intervention in Conflicts, UN, OSCE, EU, NATO, CSTO. PeaceKeeping Policies, Moscow. 
Palmer, D.A.R. (2016). The Framework Nations' Concept and NATO: Game Changer for a New Strategic Era Or Missed Opportunity?. Rome: NATO Defense College.

Payandeh, M., (2011). The United Nations, military intervention, and regime change in Libya. Va. J. Int'l L., 52, p.355.

Pedlow, W. G. (ed) (1999). NATO Strategy Documents 1949-1969 (Brussels: NATO Headquarter, 1999). http://www.nato.int/archivs/strategy.htm accessed November 2020.

Pieterse, J.Nederveen. (1991). Fictions of Europe. Race \& Class, 32(3), 1-10.

Plitnick, M. and Toensing, C. (2007). "The Israel Lobby" in Perspective. Middle East Report, (243), 42-47.

Reiter, D. (2001). NATO and Democracy-Reply. International Security, 26(3), 230-235.

Renz, B. (2019). Russian Responses to the Changing Character of War. International Affairs, 95 (4) 814-834.

Saab, Y. B. (2014). Saab on What UAE Really Wants From NATO. Foreign Affairs, Aug. 15.

Sauer, T. (2017). Take It from a European: NATO Is Obsolete. The National Interest, available at https://nationalinterest.org/feature/take-it-european-nato-obsolete-19537 accessed November 4, 2020

Scheber, T.K., (2000). US Nuclear Policy and Strategy and the NPT Regime: Implications for the NATO Alliance. Comparative strategy, 26(2), 117-126.

Segell, G. (2011). The First NATO Mission to Africa: Darfur. Scientia Militaria, vol. 36 (2) 1-9.

Seib, Philip (2014). Public Diplomacy and Hard Power: The challenges facing NATO. Fletcher Forum of World Affairs, 38(1), 95-100.

Shea, J. (2007). A NATO for the $21^{\text {st }}$ Century: Towards a New Strategic Concept, 31 Fletcher Forum of World Affairs, 31(2), 43

Simma, B. (1999). NATO, the UN and the Use of Force: Legal Aspects, European Journal of International Law, $10,1-22$.

Skelly, M. J. (2001). On the Obsolescence of Just War and Military Neutrality. Peace Review, 13(1), 115-120.

Slijper, F. (2005). The Emerging EU Military -Industrial Complex: Arms Industry Lobbying in Transnational Institute-TNI, Briefing Series (Amsterdam) 11

Sloan, S. (2016). Defense of the West, NATO, the European Union and the Transatlantic Bargain, Manchester University Press.

Solana, J. (1999). NATO's Success in Kosovo. Foreign Affairs, 70 (6), 114-120.

Stebbing, S. and Comen, E. (2019). Military Spending: 20 Companies Profiting Most from War. USA Today, Feb. 21.

Tsygankov, A.P. (2018). The Sources of Russia' Fear of NATO. Communist and Post-Communist Studies, 51 (2) available at http://DOI:1016/j.postcomstud.2018.04.002, accessed November 20, 2020.

Volker, K. and Green, P. (2011). NATO Reform: Key Principles, Atlantic Council, Issue Brief, available at https://www.files.ethz.ch/isn/136842/120711_NATO_Reform_Principles.pdf accessed November 4, 2020.

Webber, M. (2009). NATO: The United States, Transformation and the War in Afghanistan. The British Journal of Politics \& International Relations 11(1) (Jan. 21, 2009). Available at: https://doi.10.111/j.1467856X.2008.00349.x , accessed 20 November 2020.

Williams, M.C. and Neumann, I.B. (2000). From Alliance to Security Community: NATO, Russia, and the Power of Identity. Millennium, 29(2) 357-387.

Wolff, A.T. (2015). The Future of NATO Enlargement after the Ukraine Crisis. International Affairs, 91(5), $1103-1121$. 